\title{
Implementing training in Portuguese for Speakers of Other Languages in Portugal: the case of adult immigrants with little or no schooling
}

\section{Ana Raquel Matias, Nuno Oliveira \& Alejandra Ortiz}

To cite this article: Ana Raquel Matias, Nuno Oliveira \& Alejandra Ortiz (2016) Implementing training in Portuguese for Speakers of Other Languages in Portugal: the case of adult immigrants with little or no schooling, Language and Intercultural Communication, 16:1, 99-116, DOI: $10.1080 / 14708477.2015 .1113754$

To link to this article: http://dx.doi.org/10.1080/14708477.2015.1113754

Published online: 25 Jan 2016.

Submit your article to this journal ๔

Џلll Article views: 100

Q View related articles $\sqsubset$

View Crossmark data \lceil 


\title{
Implementing training in Portuguese for Speakers of Other Languages in Portugal: the case of adult immigrants with little or no schooling
}

\author{
Ana Raquel Matias ${ }^{a, b, c}$, Nuno Oliveira ${ }^{a, c}$ and Alejandra Ortiz ${ }^{a, c}$

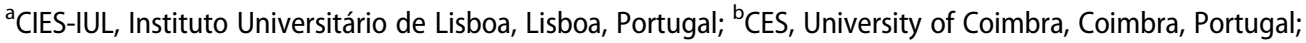 \\ ISCTE-IUL - Ava das Forças Armadas, Lisboa, Portugal
}

\begin{abstract}
Courses in Portuguese for Speakers of Other Languages, in particular for adult immigrants, have been steadily expanding in Portugal over the last 15 years. These programmes aim to promote educational and labour market integration, access to Portuguese nationality, and cognitive development. This paper argues that official Portuguese learning policies have mainly targeted a population with an immigrant background that fails to represent the full range of adult immigrants' needs. In particular, less educated adult immigrants' educational needs have been persistently neglected. Considering that, hitherto, approximately $9 \%$ of trainees have been adult immigrants with little or no schooling, this group has not received sufficient attention in policy measures, nor has it been fully accommodated in institutional terms. As a starting point, the paper identifies the place of adult immigrant literacy in international and national discussions. Subsequently, it discusses the main official programmes offering Portuguese for Speakers of Other Languages to adult immigrants. The data from the main programmes were backed up by fieldwork, in particular interviews carried out with teachers and public officials which highlight the main barriers and strategies impacting on this group. Finally, we argue that programmes should consider tailor-made solutions, given the counterproductive heterogeneity of classes and the arbitrariness of informal procedures.
\end{abstract}

A oferta do Português para Falantes de Outras Línguas destinada a imigrantes adultos tem registado uma expansão contínua em Portugal nos últimos quinze anos. Falamos de programas que têm como objectivo promover a integração escolar e profissional, o acesso à nacionalidade e o desenvolvimento cognitivo. $\mathrm{O}$ presente artigo discute como estas políticas oficiais do ensino da língua portuguesa têm tido como principal público-alvo uma população que não é representativa das necessidades globais dos adultos imigrantes. Referimo-nos em particular aos adultos imigrantes de baixa escolaridade, cujas necessidades escolares têm sido constantemente negligenciadas. Considerando que $9 \%$ do total de formandos são, efectivamente, imigrantes adultos com pouca ou nenhuma escolaridade, as necessidades específicas deste grupo não têm sido suficientemente acauteladas pelas políticas existentes, nem a sua acomodação institucional tem sido a mais

\section{KEYWORDS}

Adult literacy learners; language policies; literacy; immigrants with little or no schooling; Portuguese for Speakers of Other Languages

CONTACT Ana Raquel Matias@ raquel_matias@hotmail.com, raquel_matias@iscte.pt 
adequada. $\mathrm{O}$ artigo começa por contextualizar a literacia dos adultos imigrantes nos debates internacionais e nacionais. De seguida, analisa os principais programas oficiais de ensino do Português para Falantes de Outras Línguas para adultos imigrantes. Os dados referentes a estes programas são complementados pela pesquisa de terreno, compreendendo entrevistas realizadas junto de professores e funcionários estatais cujo foco permite elucidar as principais barreiras e estratégias com impacto neste grupo de formandos. Finalmente, argumenta que os programas devem considerar soluções mais adequadas dadas as efectivas necessidades de cada público, sobretudo tendo em conta os resultados contraproducentes de turmas demasiado heterogéneas em termos de literacia e a arbitrariedade dos processos informais em curso.

\section{Introduction}

The learning framework of Portuguese for Speakers of Other Languages has been central to the integration of non-European citizens in Portugal since 2000. This reflects the focus of European Union directives on the need to harmonize national language integration policies. It has followed a trend to standardize national discourses and policies, accompanying changes in migration regularization and integration policies, with a particular focus on acquisition of nationality. However, the 'European standardization effort' has mainly affected regulation and immigration policies, and less so the access to nationality (Bauböck, Ersbøll, Groenendijk, \& Waldrauch, 2006, Migration Integration Policy Index (Huddleston, Niessen, Chaoimh, \& White, 2011) and language integration measures (Extra \& Yağmur, 2012). Portugal can be taken as a good example of this biased standardization. The international integration index MIPEX has distinguished the country as an example of success, given its more inclusive approach to access to nationality within a larger European context of increasingly restrictive measures. Nevertheless, it continues to demonstrate the need for improvement of standards that assure continuous quality assessment of the national language learning programmes for adult immigrants. ${ }^{1}$ Particularly striking is the lack of effective language teaching for adult immigrants with little or no schooling.

We discuss the aforementioned assertion combining inputs from sociology of migration with sociology of language and education. To support this, we offer a threefold analysis which seeks to understand the ambiguous situation of adult immigrants with little or no schooling in language policies in Portugal. We begin by discussing the place of adult literacy, and particularly the literacy of adult immigrants, in Portuguese and international discussions. In this regard, we address two generalized assumptions that have influenced how existing measures have been thought out and implemented: firstly, the apparently negligible demographic representation of adult immigrants with little or no schooling; secondly, the seeming homogeneity of adult immigrants in terms of learning needs. This entails a description of the main characteristics of the immigrant and foreign population and their trends, and an examination of the main national Portuguese-language programmes for adult migrants and nationals. To this, we add findings from our fieldwork with local and national actors engaged in the design and application of these programmes. ${ }^{2}$ While acknowledging the importance of understanding the 
obstacles facing learners of Portuguese as a Second Language, which by all accounts has been researched to a paltry degree, our focus is mainly on the providers' side of these policies. We conclude by raising a number of questions on the shortcomings of the programmes examined, addressing the impact on adult immigrants with little or no schooling and their specific needs.

\section{Discussing the literacy of adult immigrants with little or no schooling}

Literacy-related discussions among international policy-makers and stakeholders have continuously focused on 'eradicating illiteracy' and improving literacy levels, while referring to the need for new understandings of literacy. ${ }^{3}$ Currently, literacy is understood not only as an individual transformation but also as a contextual and societal one, where the quality of literate environments is believed to affect how literacy is practised and understood. Despite the ongoing achievements in terms of societal and contextual responsibilities, there is still a systematic gap between the rhetoric of literacy-related policies and the actual implementation of literacy programmes and their aims. In general, measures at the national level have ultimately focused much more on improving child literacy rather than adult literacy. The latter case is frequently approached as a peripheral issue, particularly when relating to adult migrants from non-EU countries (Jarodzka, de Greef, Gouw, \& Brand-Gruwel, 2014; Morrison et al., 2011; Schramm \& Feick, 2011).

This deficit in the systematic implementation of literacy policy in contemporary societies mirrors a paradoxical sociolinguistic reality. While literacy levels have been continuously on the rise, with the recognition of the importance of functional literacy (UNESCO, 2006), 2012 data on adult literacy indicated that '781 million adults still could not read or write - two-thirds of them (496 million) were women' (UNESCO, 2014). In many countries of Western Europe, the rise in the figures on insufficient literacy skills among adults has been explained by the current migration inflows. In the case of Portugal, this is far from being purely an immigrant population issue. While the national data indicate that $24.8 \%$ of adult foreigners have had little or no schooling, that is, a full primary education or less (14.6\% have had no formal education at all), the corresponding figures for Portuguese nationals are $45.1 \%$ and $10.4 \%$ (INE, 2012). This shows that the share of this group among both the Portuguese and foreign population is far from negligible.

Moreover, the research findings and institutional documents available confirm this persistent structural need of adult literacy in Portugal. However, though adult education and training programmes embarked on a new period of good practices at the turn of the twenty-first century, mainly for a population with Portuguese as a mother tongue or fluent in the Portuguese language (Ávila, 2008; Benavente, Rosa, Costa, \& Ávila, 1996), they have suffered a rapid decline with the austerity measures in force since 2013 (Capucha, 2014; Távora, Vaz, \& Coimbra, 2012). Analyses of adult literacy and adult immigrant programmes are scarcer, though they highlight the fact that language policies have been gaining prominence within the framework of national integration policies. However, there is a continuing paucity of information and the data available scarcely refer to those with little or no schooling (Ançã, 2008; Grosso, 2010; Martins, 2014; de Oliveira, 2006; Reste \& Ançã, 2012; Semedo, 2011). In sum, if adults with no or little 
education in Portugal have been discontinuously targeted by policies or research, the situation of those with an immigrant background but similar educational needs has been taken into consideration even less.

In Europe, language policies for immigrants have been the centre of much debate, mainly with regard to the descendants of immigrants and more recently adult immigrants, in particular since the end of the 1990s and, in terms of European directives, from 2000 onwards. Previous studies of other countries have shown, in addition, various obstacles influencing the way these programmes have been conceived and implemented. On the one hand, governments that stress the importance of the official 'host country' language for adult immigrants (especially for social, economic, cultural and civic integration) are simultaneously responsible for making it harder for them to achieve these goals, through their regulations and fund-cutting (e.g. Simpson, Sunderland, \& Cooke, 2007). On the other hand, of the European countries that dispose of systematic language policies, the majority provide courses in the national language and culture, assuming that potential participants are literate in at least one language. Thus, learners are expected to pass language proficiency evaluations based on the CEFR (Common European Framework of Reference) within a very short period of time (generally six months).The main public enrolled has been, predominantly, more educated immigrants, though this group is not targeted explicitly (Van de Craast, Kurvers, \& Young-Scholten, 2006).

Consequently, these programmes have not been efficient in enabling the poorest and most marginalized adult immigrants to meet the requirements, nor are these just cases of an absolute impediment due to the individuals' illegal situation. The findings have indicated that people's socio-economic and labour status has an impact on their marginalization, as many learners are 'falling through the net' of language course criteria/language training (Sunderland \& Moon, 2008). Among these are people in precarious labour situations (e.g. working long hours in multiple jobs, with unpredictable shifts and high geographic mobility); those with little or almost no contact with the official language of the host country (independently of length of staying, or the proximity of their mother tongue to the 'host country's' official language ${ }^{4}$ ); and those having little or no schooling. And because these types of status are not mutually exclusive, they tend to reinforce each other. When there are no suitable literacy classes for these learners, their inclusion in the existing range forces learners to do two things at the same time: learn a foreign language and learn how to read and write. In these situations, teachers and trainers face, in the same learning context, adult learners with contrasting pedagogical needs. Portugal is no exception, which leads us to the second assumption: the apparent homogeneity of adult immigrants' learning needs. This assumption ignores the diversity of this population in terms of their formal educational attainments (if any), linguistic background, social status, labour market trajectories, and prior personal experience of the Portuguese language.

In the next section, we will consider the category 'adult immigrants with little or no schooling', that is, those who have had no formal education or have completed, at most, a primary education. This socio-demographic categorization allows the empirical identification of those with a higher likelihood of having few or no literacy skills in any language. However, we are aware that identifying individuals through formal education carries certain limitations: On the one hand, because literacy may be acquired in 
another language outside the compulsory and formal education system; on the other hand, when analysing individual linguistic socialization experiences, those with more than a primary and formal education may still have insufficient literacy skills in any language. Nevertheless, the option to identify the subjects through their formal schooling allows us to indirectly estimate their demographic weight among the total of adult immigrants. This refers to both national data (the census and specific policies implemented) and international comparisons. ${ }^{5}$

\section{Immigrants and their educational levels}

Immigration in Portugal is mainly characterized by labour migration and subsequent family reunification. The migration flows have reflected economic, political and migration policy developments which, for the purpose of this paper, can be divided into two main phases: an earlier phase, stretching from the mid-1970s to the late 1990s, when the bulk of the immigrants came from Brazil and African countries with Portuguese as an official language (PALOP), ${ }^{6}$ that is, former colonies such as Cape Verde, Angola and Guinea-Bissau (though, for many, Portuguese was a second language); and a later stage, which stretched from the late 1990s to the early 2000s, when the immigrants' origins were greatly diversified. Most of the new immigrants were labour migrants from the postSoviet European states (particularly Ukraine and Moldova) and different ethnic groups in Asia (with an Indian, Pakistani, Bangladeshi or Chinese background) and, to a lesser extent, refugees and asylum seekers from Africa, Asia and Latin America (Baganha, 2005; Fonseca, Ormond, Malheiros, Patrício, \& Martins, 2005; Padilla \& Ortiz, 2012; Santinho, 2012).

Currently, the main nationalities living in Portugal are citizens from Brazil (92,120; 23\% of all foreign residents), Cape Verde (42,401, 11\%), Ukraine (41,091, 10\%), Romania (34,204, 9\%), Angola (20,177, 5\%), China (18,637, 5\%), Guinea Bissau (17,846, 4\%) and the UK $(16,471,4 \%)$, with the remainder representing roughly $29 \%$ (SEF, 2013). The foreign population as a whole amounted to 401,320 in 2013 , approximately $3.5 \%$ of the total resident population. The great majority of immigration flows are work-related ( $84 \%$ of the whole foreign population are 15-64 years old), and there are more foreign women than men (51.3\% vs. $48.7 \%)$, particularly among those from Brazil, Cape Verde and Angola.

The educational attainment of the foreign-born in Portugal reveals a striking feature of the national educational structure, as the education levels of working-age people (age range 15-64) are on average higher for the foreign population (see Figure 1). While the proportion of foreigners with less than a lower secondary education was $28.2 \%$ in 2013 , this figure stood at $40.6 \%$ for the Portuguese population. Similarly, the $32.7 \%$ of foreigners with an upper secondary or post-secondary education contrasts with the less than $20 \%$ in the case of nationals. Only at the tertiary education level were foreigners (slightly) less represented than the Portuguese (14.4\% and $16.6 \%$, respectively). However, foreigners are not a homogeneous group in terms of educational profiles (see Figure 2). Those from the PALOP countries are, in general, the least educated, particularly those from Cape Verde, Guinea-Bissau and Angola, together with those from China; conversely, those from European Union countries, non-EU Eastern European countries and Brazil show educational levels that are considerably higher than the first group and, on average, higher than the native-born population, as illustrated in Figure 2. 


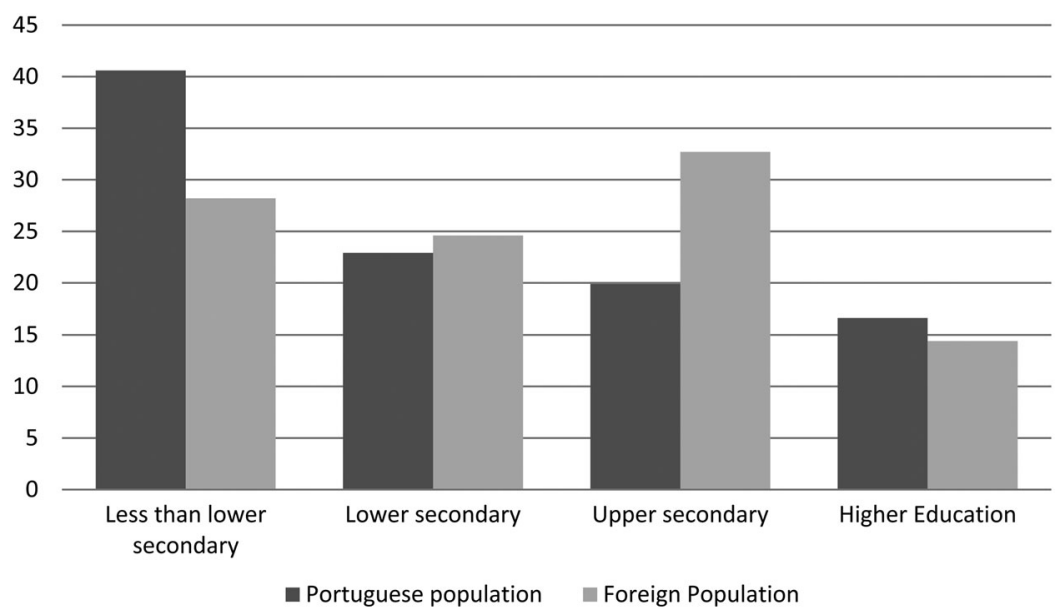

Figure 1. Population in Portugal by nationality and education level (2012).

Source: INE, Demographic Statistic, 2012.

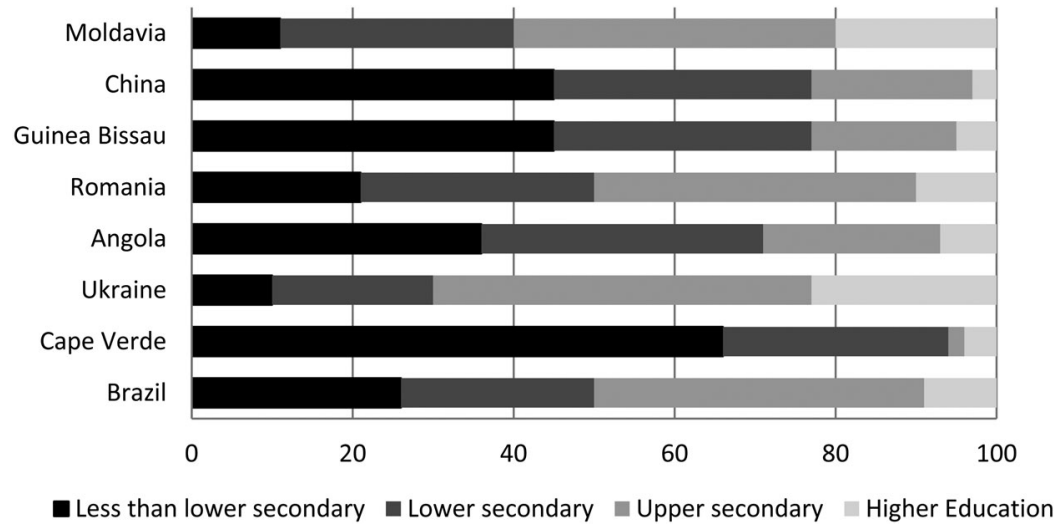

Figure 2. Main foreign population by nationality and education level (2012).

Source: INE, Demographic Statistic, 2012.

Regarding integration into the employment market, studies have shown that this is highly segmented. While African, Eastern European and second-wave Brazilian immigrants are mostly concentrated in the secondary job market, European, NorthAmerican and first-wave Brazilian immigrants are concentrated in the primary job market (Marques \& Góis, 2008; Peixoto \& Abreu, 2009; Peixoto, Marçalo, \& Tolentino, 2011).

As pointed out above, the foreign population in Portugal is highly diverse in its linguistic, educational and labour market characteristics, a reflection of diverging integration needs at various stages. This provides a highly heterogeneous landscape that existing policies have not fully considered when aiming at optimizing language integration policies. Given that the linguistic needs of immigrants are one of the basic conditions for their successful integration into Portuguese society, we will discuss this issue in the following section. 


\section{The road to the institutionalization of language learning programmes and the enduring gap}

Adult education and training policies in Portugal may be grouped into those that focus on the need to improve adult education and training skills and those that focus on Portuguese language competencies. For the first, we find the programme Recurrent Education (since 1986) and the New Opportunities Initiative (2005-2011). ${ }^{7}$ The second group comprises the programmes Basic Skills (Competências Básicas, CB, from 2010 onwards), Portugal Welcomes (Portugal Acolhe, PA, 2001-2007) and Portuguese for All (PPT, from 2008 onwards). Only the latter two targeted foreigners and those with an immigrant background, though they did not explicitly exclude Portuguese citizens.

The second group of programmes have been sequentially implemented since 2001, thus widening the scope of language acquisition efforts that have accompanied migration trends (see Table 1). They represent the official side of a process already set in motion, in piecemeal fashion, by grass-roots organizations, the Catholic Church, schools and universities, for nationals and foreigners alike. However, most of these initiatives were carried out on a voluntary basis and outside the official educational system. For these reasons, official action became part of the national integration plans for residents with an immigrant background: it reflected a steady increase in the supply of participants. First of all, Portugal Welcomes (PA) enrolled a total of 13,152 immigrant trainees during its period of operation (AAVV, 2006/2007), ${ }^{8}$ followed by PPT, which enrolled 37,742 trainees (figures for 2012).

The official system can be dated from 2001, with the programme Portugal Welcomes (PA). This measure was designed for rapid incorporation into the job market by upgrading immigrants' language skills to a minimum functional level. The programme was implemented under the aegis of the IEFP (Institute of Employment and Professional Training IP), ${ }^{9}$ through its network of employment and vocational training centres, in association with other bodies such as ACIME (High Commissioner for Immigration and Ethnic Minorities) and certain Non-governmental organizations. The training was divided into a longer part (150 hours) that developed the ability to understand and speak Portuguese and a shorter one (12 hours) that taught the participants labour rights and the duties of active citizenship (IEFP, 2002). At this stage, PA did not yet fit into the European Language Framework, offering a Basic Portuguese Module instead.

Table 1. Main official Portuguese language programmes.

\begin{tabular}{|c|c|c|c|}
\hline Name & Duration & Organization & Main Goals \\
\hline $\begin{array}{l}\text { Portugal } \\
\text { Welcomes }\end{array}$ & $\begin{array}{l}2001- \\
2007\end{array}$ & $\begin{array}{l}\text { Ministry of Labor State } \\
\text { IEFP } \\
\text { ACIME }\end{array}$ & $\begin{array}{l}\text { Acquisition of the Portuguese language } \\
\text { Acquisition of knowledge on labour rights and duties } \\
\text { associated with active citizenship (citizenship module) } \\
\text { (Incorporation of Eastern European migrants in the job } \\
\text { market) }\end{array}$ \\
\hline PPT & $\begin{array}{l}2008- \\
2013\end{array}$ & $\begin{array}{l}\text { ACIDI } \\
\text { IEFP } \\
\text { POPH-EU }\end{array}$ & $\begin{array}{l}\text { Learning Portuguese language and expanding } \\
\text { Portuguese learning integrative potentials (Diversity as a } \\
\text { paradigmatic concept of a governing model for the } \\
\text { Portuguese policies) Language as integration tool }\end{array}$ \\
\hline Basic Skills & $2010-$ & $\begin{array}{l}\text { ANQ Agency for National } \\
\text { Qualification (Lisbon Strategy } \\
\text { 2020) }\end{array}$ & $\begin{array}{l}\text { Acquisition of language skills for nationals with little or } \\
\text { no literacy. } \\
\text { Improving adults' education (reading, writing, arithmetic } \\
\text { and IT) }\end{array}$ \\
\hline
\end{tabular}


Provided by National Agency for Adult Employment and Training (ANEFA), this was divided into the levels initiation, consolidation and strengthening for nationals and foreigners and was backed up with the Portuguese as a Second Language Manual.

As pointed out above, this measure should be seen in the context of a turning point towards more diversified immigration in terms of official languages, cultures, educational levels and occupations. Notably, the mounting inflows of immigrants from Eastern Europe with academic qualifications far higher than the settled immigrant population would come to rank among the 10 largest immigrant communities (in particular those from Ukraine, Romania and Moldova). PA was designed with this specific public in mind, as explicitly mentioned in its principal official documents and further studies (Vinhas \& Matias, 2002). The translation of its Welcome Manual into five languages - Ukrainian, Russian, Romanian, French and English - reflects its target public. According to the 2006 and 2007 Implementation Reports, 840 Portuguese learning initiatives were carried out under the PA programme between 2001 and 2007, involving a total of 13,152 trainees from more than 50 countries, with a slightly higher proportion of women than men $(55 \% \mathrm{vs}$. 45\%). The great majority were from Eastern Europe (77\%), particularly Ukraine (59\%), Russia (18\%), Moldova (6\%) and Romania (5\%). Among the PALOP countries, the most highly represented were Guinea Bissau, Cape Verde and Angola, though their share was only $1 \%$ of the learners. The majority of trainees had an upper secondary education (34\%), lower secondary (22\%) or tertiary education $(21 \%)$, while the proportion of trainees with little or no schooling (mostly of African origin) was 5\% (for an overview, see AAVV 2001/2002, 2003, 2004, 2005, 2006/2007; Silva, 2003). As reported, the lack of literacy modules represented a serious gap in the language learning courses, as a nonnegligible part of potential trainees could be assumed to have little or no schooling.

The shortcomings detected in Portugal Welcomes, such as low attendance and lack of diversity of national and educational backgrounds triggered the formulation and setting up of the new programme PPT in 2008. This transition accompanied the extension of the powers of the ACIME and translated into a gradual sharing of powers between the latter and IEFP. This occurred with the extension of the ACIME remit through the creation of the High Commission for Intercultural Dialogue (ACIDI) in conjunction with the National Action Plan for Inclusion 2006-2008 (PNAI), in which, for the first time, the need to strengthen citizenship education and training to improve the 'assimilation, integration and employability of immigrants ${ }^{10}$ was explicitly addressed and legally incorporated (ACIDI 2005/2008; ACIDI 2010). This boosted the implementation of intercultural modalities of education, assuming intercultural dialogue to be paramount in the new model. In addition, Portuguese as a Non-native Language (PLNM) in schools was deemed to be fundamental for the descendants of immigrants, while the scope of the acquisition of Portuguese by adult immigrants was gradually widened. Thus, in the second stage, ACIDI, as an intermediate Human Potential Operational Program (POPH) body, ${ }^{11}$ took over the initiative of managing and disseminating the new state programme.

Like its predecessor, PPT was implemented nationwide. Set up within the scope of Training in Portuguese for Foreigners, ${ }^{12}$ it sought to generate additional action to promote the acquisition of technical Portuguese in order to facilitate labour market access, according to the needs identified in strategic job sectors. It incorporated the CEFR for Languages established by the Council of Europe in 2001, to which proficiency 
levels B1 and B2 were added in 2011. Over a period of four years (2008-2012), 37,742 trainees attended PPT classes, with the number of enrolled trainees increasing by over $70 \%$ during this period and soaring to $83 \%$ in the period 2008-2009. However, the distribution of nationalities and educational levels maintained the same structure as that observed for the first programme. Eastern Europeans formed the majority, with citizens from African backgrounds contributing the smallest share of learners (see Figure 3). The majority of trainees had an upper secondary education, followed by those with a higher education; women were overrepresented in both groups (see Figure 4). Once again, the proportion of trainees with less than a lower secondary education was non-negligible, accounting for $8 \%$ of the total, in this case with men being overrepresented. A comparison by nationality and educational level clearly shows how skewed the distribution of trainees is, repeating the same unbalanced structure observed previously in the PA programme. The bulk of learners from Eastern European countries have higher educational qualifications than the remaining nationalities, while citizens from Guinea Bissau, China and Romania figure prominently among the least educated. ${ }^{13}$

In spite of all the modifications introduced, a previous module on citizenship was excluded and a literacy module was still missing. The former decision meant that attention was restricted to language learning; the latter that $8 \%$ of trainees were not provided with the right pedagogical process. ${ }^{14}$ This was often the main reason for participants with no or little education prematurely dropping out, also according to our interviewees (see next section). Otherwise, attempts were made to overcome these situations using informal strategies enacted by trainers in the classroom, as will be briefly mentioned in the next section. Despite these limitations, available figures in the evaluation report summary show success rates steadily under $70 \%$, with the lowest achievement rate at $28 \%$, in 2008, and the highest rates in 2011 and 2012 (66.9\% and 62.4\%) (AAVV, 2014). ${ }^{15}$

The latest Portuguese language learning programme for adults, Basic Skills (CB), was set up in 2010 following the recommendations of the Lisbon Strategy 2020 for adult education and training in lifelong learning. It is a programme for the acquisition of language skills by

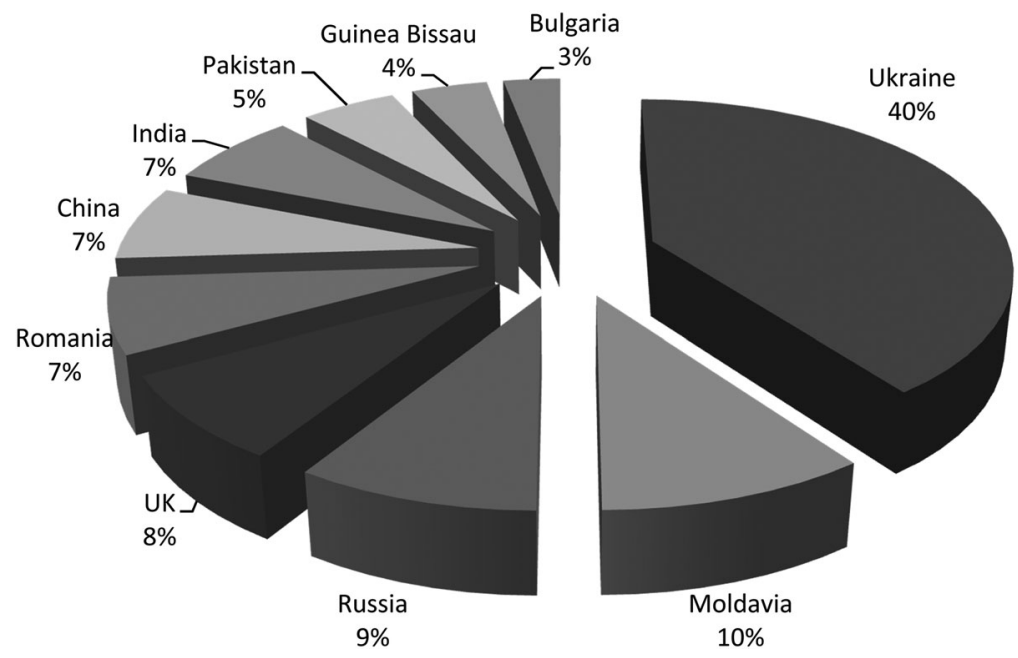

Figure 3. PPT-Trainees by main nationalities (2012).

Source: ACIDI, PPT. 


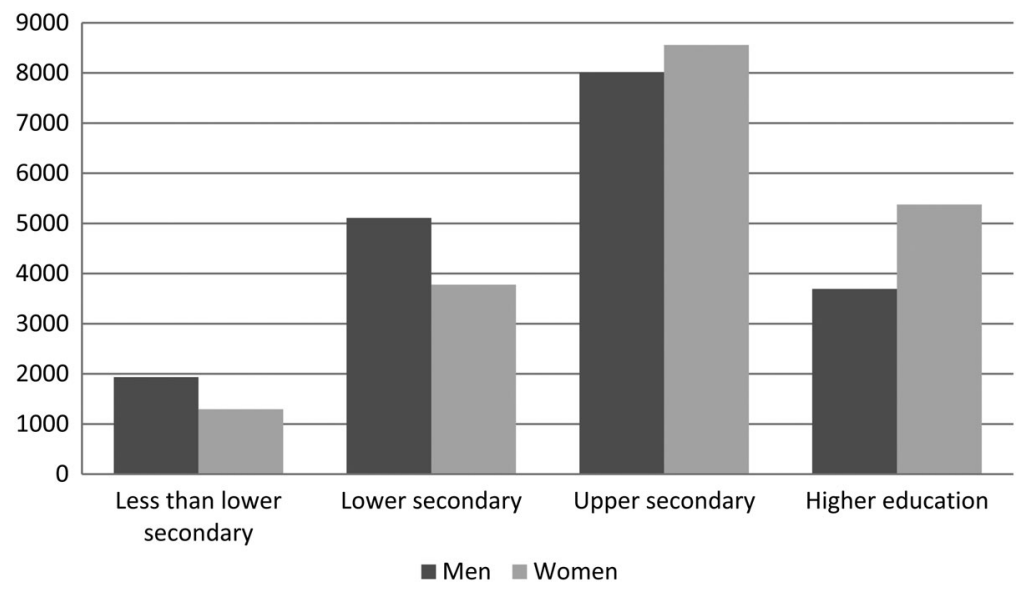

Figure 4. PPT-Trainees by level of education (2008-2012).

Source: ACIDI, PPT.

adults who have little or no literacy in Portuguese and is intended for native speakers or individuals with intense and continuous contact with the Portuguese language, irrespective of their nationality. The CB programme is divided into short training units within the National Qualifications Catalogue, addressing the adult literacy skills required for a more qualified educational trajectory - reading, writing, arithmetic and Information Technology (IT) - as well as providing a route back to the educational system for those who have failed to complete their school careers. While it has mainly targeted a native-born public, it has been used as a surrogate track to redirect foreigners with no or little literacy in any language who are dropping out of the official Portuguese language training courses (as reported by our interviewees).

According to 2012 data, this programme targeted 9144 unemployed people, some on Social Integration Benefit, with no skills yet to qualify for the national education system. Of the CB population, $15 \%$ were trainees who could not read or write, $28 \%$ had some literacy but no formal education, and $57 \%$ had a full primary education at most but no literacy skills in reading and writing or arithmetic. ${ }^{16}$ The combined failure and dropout rates amounted to $27 \%$ in 2012; for the success rate, however, the distribution by nationality is not available. The data are only broken down by nationality at the general attendance level in 2012: it reports a rate of $11 \%$ for foreigners and shows a striking contrast with the PTT target public. In this case, the majority of foreign trainees were from Portuguese-speaking countries, with Eastern Europe having little prominence (see Figure 5).

This state of affairs has two main consequences. Given that only this specific programme has a literacy module, foreigners with few or no literacy skills in any language are generally channelled into the literacy programme during the selection process for the Social Integration Benefit. However, on account of their low levels of education and literacy in their mother tongue or any other language, they face serious difficulties when learning to read and write in courses that mainly target Portuguese-speaking participants. The materials and manuals are tailored for trainees with Portuguese as a mother tongue or those who have already had long and sustained contact with the language. 

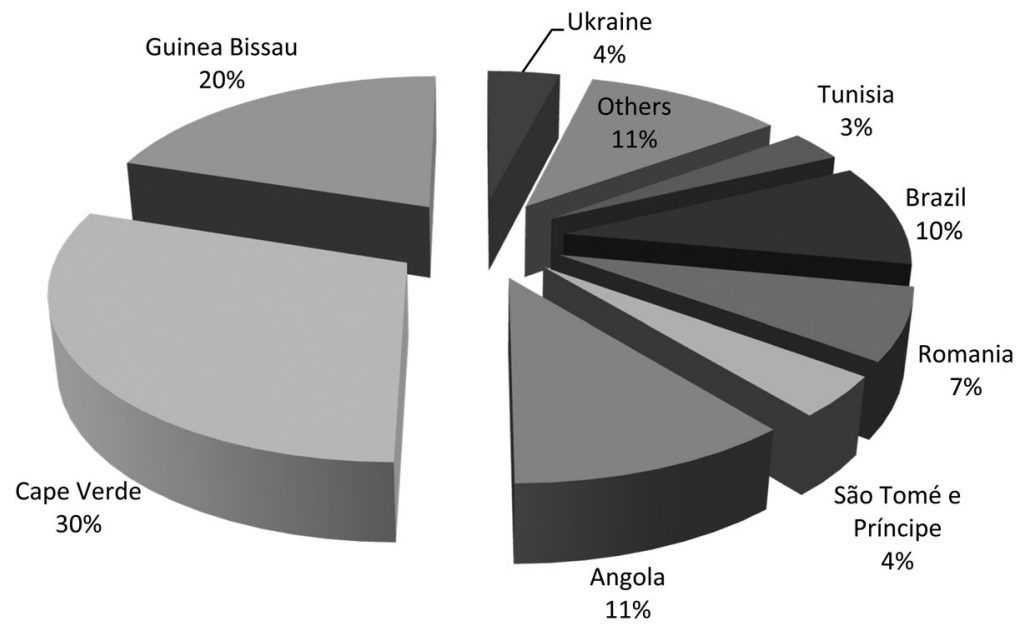

Figure 5. Basic Skills Trainees by main nationalities (2012).

Source: Professional Training Department, IEFP.

In short, none of the above-mentioned programmes has dealt adequately with adult immigrants with little or no schooling. In the next section, we will look briefly into the main challenges that this public presents, as reported by our interviewees.

\section{Learning from the field: barriers and strengths in the teaching of Portuguese for Speakers of Other Languages}

Any account of programmes implementation would not be complete without key actors' own experiences and perceptions. In this section, we seek to identify teachers' strategies to accommodate different pedagogical needs in the classroom. We conducted eight exploratory semi-structured interviews, five with trainers/teachers from the PPT/CB programmes and NGO literacy courses, one with the coordinator of the only PPT evaluation, and two with national institutional representatives of the PPT and PA programmes. ${ }^{17}$ The interviews took place between 2014 and 2015 in the Lisbon area in schools, employment centres, community associations, the university and the national High Commission for Migrations (ACM). They focused on the trainers and teachers' experiences and education, as well as the strategies and representations employed by different actors while working with trainees of various immigrant, national and cultural backgrounds, in particular those with no or a low educational level. Our goal was to assess the limitations and strengths reported by different actors during the courses and to understand the transitions between the different programmes. An exploratory content analysis and the identification of the main themes and dimensions was carried out.

The interviewees reported that, from the beginning of this process, instrumental motivations to learn Portuguese prevailed over the desire to learn the language for itself. Among the main reasons were the programmes' own aims, that is, to closely co-ordinate language policy, immigration policies and naturalization. This involved creating the conditions not only to teach Portuguese but also - mainly - to offer individuals the tools for obtaining 
Portuguese nationality or a long-term residence permit. In other cases, it was a way to maintain trainees' access to social benefits.

Among the most commonly reported shortcomings were five organizational criteria, particularly regarding the main programme operating at present - PPT. These were the legal obligation of a minimum of 25 trainees per class; the time-consuming process of getting Ministry of Education permission to commence each course; the different processes of initiating PPT and CB courses in training and employment centres compared to those in schools; the application of diagnostic tests to trainees after the course has begun and the learners have already been divided into classes; the ban on transferring trainees between classes.

The obligation of at least 25 trainees was reported as hindering the efficiency of the teaching, for two main reasons. On the one hand, it is often the reason to continuously postpone new classes at more advanced levels (e.g. B1 and B2) - about 80\% of trainees only go as far as Level A2. On the other hand, it not only works against the trainees' need to adapt to different schedule obligations, but makes it considerably more difficult to follow the participants' learning processes individually, which the subgroup of low-literacy learners requires. Recently, this criterion was reported to be changing from 2015 . The time-consuming process of getting permission to start new classes in schools hosting PPT, together with the different schedules between schools, employment/training centres and NGOs, hampers class formation and learner transfers between the different partners.

Moreover, though diagnostic tests could be applied at any moment, in general, they were only applied once the classes had started, which proved to be harmful to the smooth running of the programmes. This would delay the assessment of the trainees' specific profiles to the point where they could no longer be transferred to more suitable classes in other locations. When CB places were unavailable, this often resulted in these trainees joining classes where teachers or trainers allowed them to attend but where they sat with trainees with contrasting pedagogical needs. This situation was said to promote different 'speeds' in the classroom, making the teachers and trainers' work particularly demanding. In addition, when trainees experienced tight schedules for jobfamily-learning obligations, or their job/family conditions changed, the PPT offered no possibility of a transfer to other schools/classes. The latter two situations were reported as the main reasons that participants dropped out.

The reasons for some trainees not being transferred to CB courses were reported by the trainers and teachers as involving both institutional constraints and individual motives. Regarding the former, there are often no CB places for these learners, which means that they are reintegrated into the PPT programme to acquire a minimum language knowledge, even if without certification. As for the second aspect, trainees may recognize that $\mathrm{CB}$ is shaped for Portuguese native speakers, or those fluent in Portuguese, and therefore anticipate experiencing significant difficulties. Furthermore, with PPT trainers and teachers, they hope for better pedagogical content and more sensitive methodologies that uphold their self-esteem during the learning process, thus enhancing their likelihood of success. These considerations lead us to another issue: teachers of Portuguese as a second language are rarely trained to teach adults from such diverse national, social, economic and cultural backgrounds - especially adult immigrants with little or no schooling. Only recently have new perspectives on this issue been systematically discussed - to a large extent as an 
outcome of the experience of these programmes, as well as the need to mainstream the learning of Portuguese for Speakers of Other Languages worldwide. ${ }^{18}$

On the other hand, the strengths highlighted were related to the strategies for overcoming the limitations that teachers and trainers had to face: firstly, the flexibility in evaluating individual learning, through a form of continuous and non-uniform evaluation adapted to the trainees' profiles, the trainers' strategies and the specific learning context; secondly, the consensual recognition of the undeniable impact of these programmes on learners' lives in terms of sociability and the combating of isolation. This point was a significant advantage reported by all actors. The enrolment of trainees in these programmes implied, from the first moment, a start-up phase for obtaining formal skills, developing significant language and cultural contact within the classroom and among the different actors, and producing individual gains in terms of more and better skills within and without the family context (e.g. in communications with schools, employers and other institutions). Moreover, the involvement of different generations of the family was also reported as motivating individual learning processes.

\section{Conclusion}

A number of conclusions can be drawn from this overview of Portuguese policy and the institutional and pedagogical dynamics at work in the field of second language acquisition among adult immigrants.

Firstly, adult foreigners with little or no schooling have not received sufficient attention in policy measures and, thus, have not been incorporated as they should. These findings mirror a national environment where adult education has long been a structural problem hindering both individual equality of opportunity and the country's social development. Though this is a well-documented issue, it has not been targeted correspondingly, as a policy priority. There is still a need for a systematic, continuous and coherent policy on adult literacy, particularly for citizens with no or few literacy skills. However, while Portugal lags behind most European countries in adult education in general (on account of defective policy implementation), its needs for improvement in adult immigrant language policy are common at an international level, as mentioned previously, with few exceptions (AAVV, 2012; Petrova, 2012).

Secondly, ongoing fieldwork has shown how teachers and trainers deal with the lack of a suitable framework, appropriate content and defined methods for adult immigrants with little or no schooling. While there is no literacy module currently in place for Portuguese for Speakers of Other Languages, and the teachers and trainers have no specific training according to the target population's needs, strategies range from informally and individually assessing the literacy level of the students to using visual aids to overcome non-recognition of the alphabet. In most cases, this has implied extra work and considerable personal involvement on the part of the trainers and teachers. This may lead to arbitrary results for the trainees, as their learning success depends greatly on the availability and level of concern of the teachers, as well as the constraints of the specific learning environment.

Thirdly, heterogeneous classes, combining uneducated or little educated with more highly educated trainees, are counterproductive, given the differential in the learning pace between the different groups. This understanding provides teachers and trainers 
with tools to ascertain learners' personal socialization in Portuguese, which is the main focus of the learning process under analysis. Some learners need to develop or obtain skills in Portuguese as a foreign language using the alphabet of their mother tongue; some use a completely different alphabet; others have acquired the Portuguese language as a second and post-colonial language (e.g. learners with a PALOP background) or as a second language related to their family's immigrant background. Those who are in one of the above situations and have little or no schooling need to learn Portuguese by means of literacy methods applied to their specific linguistic capital.

Fourthly, the alleged minor significance of adult immigrants with little or no schooling - seen as a generational trait limited in time - underestimates the actual demographic dimension as well as the intergenerational weight of language dynamics in individual trajectories and linguistic socialization experiences. In other words, language holds a central role as it represents one of the main tools for successful individual and group adaptation, particularly within the family (Brizić, 2008; Chiswick, Lee, \& Miller, 2005).

In sum, the conception of 'one-size-fits-all' is unconvincing. Teaching procedures and methodologies need to be adapted to learners' needs and social practices, implying more in-depth knowledge on this public profile and trajectories (see, inter alia, Schöneberger Schöneberger, van de Craats, \& Kurvers, 2011). In this paper, we indicated gaps in the programmes involving Portuguese for Speakers of Other Languages, relating to those most likely to possess insufficient literacy skills in any language. Insofar as it is consensual that language is a key factor in the advancement of individual integration into society at all levels, the urgent need for this specific population to overcome their limitations has, paradoxically, been neglected. Hitherto, the solution has been either to redirect them to literacy classes within adult literacy courses for native speakers or to devise informal strategies within the PPT classroom setting. Either way, there is a great likelihood of their not succeeding in terms of certification, even though the PPT actors are far more adapted to dealing with immigrant learners. In a nutshell, this means that, while tailormade programmes are needed for the immigrant population in general, they are greatly needed for this segment in particular. The article's specific focus on public agents and decision-makers does not preclude the need to study trainees' own experiences in regard to programmes methodologies and language acquisition processes. Indeed, in order to understand in more detail their trajectory in formal and informal Portuguese learning courses, further studies, namely of ethnographic nature adapted to this public profile, are needed.

\section{Notes}

1. For instance, if between 2001 and 2006 there were mainly internal reports for the first implemented programme, from 2006 onwards, one-single external evaluation on the subsequent programme was issued.

2. These findings are the outcome of an ongoing research project on implementation of training in Portuguese for Speakers of Other Languages in Portugal established in Centre for Research and Studies in Sociology (CIES-IUL).

3. To give greater detail, this advance has been gradual and has reflected several periods, declarations and reports: to start with, the 1949 United Nations General Assembly's vision of the minimum requirements for basic education; then the onset of the Cold War; later, the World Declaration on Education for All and its main documents $(1990,1996)$, in conjunction 
with International Literacy Year (1990); the 1996 Report of the International Commission on Education for the Twenty-first Century; the 1997 Hamburg Declaration (emphasizing the relationship between lifelong learning and active community engagement); the 1997 OECD report on Literacy Skills for the Knowledge Society; the Dakar Framework for Action in 2000; and, recently, the United Nations Literacy Decade (2003-2012) and Resolution 56/116 acknowledging the place of literacy at the heart of lifelong learning (UNESCO, 2006). See also overview in Petrova (2012).

4. These may refer to socio-economic situations that reinforce the isolation of individuals: those employed in 'ethnic work units' or who work in jobs where they are isolated and do not use their oral or written language skills, or who are isolated for other social or cultural reasons - gender-related problems resulting in imbalances and inequality, or emotional barriers such as those confronted by asylum seekers and refugees.

5. This follows other definitions used in international studies, in particular the literature on the LESLLA learners since 2005, e.g. Young-Scholten et al.(forthcoming).

6. The PALOP, Portuguese-speaking African countries.

7. In Portuguese: Educação Recurrente and Iniciativa Novas Oportunidades.

8. Sumário Executivo Portugal Acolhe 2006-2007 [Executive Summary Portugal Welcomes 2006-2007], IEFP.

9. IEFP, supervised by the State Secretariat at the Ministry of Labour and funded by POEFDS (Operational Programme for Employment, Training and Social Development).

10. National Agency for Adult Employment and Training.

11. Human Potential Operational Programme (Decision C (2007) 5157).

12. Order No. $18476 / 2008$ of 10 July.

13. At the time of writing, data on the breakdown by education level and nationality for PPT were not available. This inference is based on exploratory interviews conducted among PPT trainers, both in schools and in employment centres.

14. Considering those with primary education or less, as mentioned in the first part of this article.

15. Data obtained from the High Commission for Migration (ACM, former ACIDI) and the Interim Evaluation Study of the PPT programme, July 2014. Data for 2013 and 2014 are not yet available.

16. Data provided by Professional Training Department, IEFP, Portugal.

17. At the time of writing, the national responsible for the $\mathrm{CB}$ was not yet available for interview.

18. On this matter, see the Teachers' Portal for Portuguese Foreign Language (Portal do Professor de Português Língua Estrangeira/Língua Não Materna), in International Institute for the Portuguese Language (IILP), from the Community of Portuguese-Speaking Countries (CPLP), http://www.ppple.org/conversa, an ongoing project including different researchers.

\section{Disclosure statement}

No potential conflict of interest was reported by the authors.

\section{Notes on contributors}

Ana Raquel Matias is currently a Post-Doctoral researcher at the Centre for Research and Studies in Sociology (CIES-IUL) and Centre for Social Studies (CES, University of Coimbra). She is studying language policies and language attitudes in Portugal, focusing on adults and children of immigrant and African background. She holds a Ph.D. degree in Sociology at Instituto Universitário de Lisboa (ISCTE-IUL) and the National Institute of Demographic Studies (INED, Paris), with a Marie Curie Fellowship, a Ph.D. grant from the Portuguese Science and Technology Foundation (FCT), and a short-term grant from Fundação Calouste Gulbenkian (FCG) to visit the Centre d'Études et de Recherches Internationales (CERI, Sciences Po). Her doctoral studies were framed in the international TIES project (The Integration of the European Second Generation), focusing on selfreported bilingual outcomes and language acculturation among descendants of Turkish immigrants 
in Germany, France and the Netherlands. She specialized in the intersection between sociology of migration and sociology of language, comparing policies on immigration, language integration and education.

Nuno Oliveira is currently Post-Doctoral researcher at Centre for Research and Studies in Sociology (CIES-IUL) Instituto Universitário de Lisboa (ISCTE-IUL) and at the Max Planck Institute for the Study of Religious and Ethnic Diversity. He is developing work on the meaning of governance of diversity models, both in Europe and in Latin America, with a special focus on the meaning of interculturality in Portugal. He holds a Ph.D. in Sociology from the Instituto Universitário de Lisboa (ISCTE-IUL) and among other things, he worked for the Fundamental Rights Agency of the EU as a detached national expert and was the coordinator of the Portuguese National Focal Point of the European Racism and Xenophobia network (Raxen).

Alejandra Ortiz is a Ph.D. student in Sociology with a doctoral Fellowship by the Portuguese Science and Technology Foundation (FCT) with a doctoral project on health citizenship in immigrants mothers; she holds a Master in Sociology and a Post-graduation in Data Analyse from the Instituto Universitário de Lisboa (ISCTE-IUL) and a Licenciatura (BA) in Sociology from the University of Social Sciences of Uruguay (UDELAR). Currently, she is a junior research at the Centre for Research and Studies in Sociology (CIES-IUL) and collaborates in several research projects and international networks. Her research interests are migration, citizenship, health inequalities, public policy and Latin America. She has published in Spanish and Portuguese in national and international scientific journals.

\section{References}

AAVV. (2001/2002, 2003, 2004, 2005, 2006/2007). Programa Portugal Acolhe. Relatórios de Execução [Programme Portugal welcomes. Implementation reports]. Lisbon: Departamento de Formação Profissional, Núcleo de Desenvolvimento Social e Profissional, IEFP.

AAVV. (2012). ILLIAD lessons learned (Policy recommendations). In Intercultural language learning for illiterate adults. Education and culture DG, lifelong learning. program. Retrieved from http://www.illiad.eu/images/PDF_files/illiad-policy-recommendations-v2.pdf

AAVV. (2014). Estudo de Avaliação Intercalar do Programa PPT-Português para Todos (20092012). Sumário Executivo [Interim evaluation study of the programme PPT-Portuguese for all. Executive summary], Nuno Dias e Assunção Gato (coord.) Dinâmia-CET, Lisbon, ACM, IP.

ACIDI. (2005/2008). Plano de Actividades Acolher para Integrar - Mais e Melhor [Work plan welcoming for integrating - More and better]. Lisbon: Presidência do Conselho de Ministros.

ACIDI. (2010). Relatório Final do PII (2007-2009) (Final PII Report (2007-2009). Presidência do Conselho de Ministros. Lisbon: ACIDI. Retrieved from http://www.acidi.gov.pt/acidi-i-p-/ documentos-acidi/plano-para-a-integracao-de-imigrantes-pii].

Ançã, M. H. (2008). Língua portuguesa em novos públicos [The Portuguese language among new publics]. Saber (e) Educar, 13, 71-87.

Ávila, P. (2008). Os contextos da literacia: percursos de vida, aprendizagem e competências-chave dos adultos pouco escolarizados [The contexts of literacy: Life courses, learning and key competencies of low educated adults]. Sociologia, 17/18, 307-337.

Baganha, M. I. (2005). Política de Imigração: A regulação dos fluxos [Migration Policy: Regulating the flows]. Revista Crítica de Ciências Sociais, 73, 29-44.

Bauböck, R., Ersbøll, E., Groenendijk, K., \& Waldrauch, H. (Eds.). (2006). Acquisition and loss of nationality, volume 1: Comparative analyses: Policies and trends in 15 European countries. Amsterdam: Amsterdam University Press.

Bauböck, R., Ersbøll, E., Groenendijk, K., \& Waldrauch, H. (Eds.). (2006). Acquisition and loss of nationality, volume 2: Policies and trends in 15 European countries. Amsterdam: Amsterdam University Press.

Benavente, A., Rosa, A., Costa, A. F., \& Ávila, P. (1996). A Literacia em Portugal: Resultados de uma Pesquisa Extensiva e Monográfica [Literacy in Portugal: Outcomes of an extensive and monographic research project]. Lisbon: Fundação Calouste Gulbenkian. 
Brizić, K. (2008). Educational profit through language loss? A sociolinguistic-explorative answer to open questions in migration and education research. International Journal of Anthropology, 23 (3-4), 185-196.

Capucha, L. (2014). Iniciativa Novas Oportunidades, o Tempo da Igualdade [The new opportunities initiative. The time for equality]. In M. de L. Rodrigues (Ed.), 40 Anos de Políticas de Educação em Portugal - Vol. I - A construção do sistema democrático de ensino (pp. 393-410). Lisbon: Almedina.

Chiswick, B., Lee, Y., \& Miller, P. (2005). Family Matters: The role of family in immigrants' destination language acquisition. Journal of Population Economics, 18(4), 631-647.

Extra, G., \& Yağmur, K. (org.) (2012). Language rich Europe: Trends in policies and practices for multilingualism in Europe. Cambridge, MA: Cambridge University Press.

Fonseca, M. L., Ormond, M., Malheiros, J., Patrício, M., \& Martins, F. (2005). Reunificação Familiar e Imigração em Portugal [Family reunion and immigration in Portugal]. Observatório da Imigração de Portugal, ACIDI. Retrieved from www.oi.acidi.gov.pt

Grosso, M. J. (2010). Língua de acolhimento, língua de integração [Host language, integration language]. Horizontes de Linguística Aplicada, 9(2), 61-77.

Huddleston, T., Niessen, J., Chaoimh, E., \& White, E. (2011). MIPEX migrant integration policy index III. Brussels: British Council, Migration Policy Group.

IEFP. (2002). Programa Portugal Acolhe. Guia do Formando. Módulo Básico de Cidadania. Guia do Formador [Programme Portugal welcomes. Trainee's guide. basic citizenship module. Trainers' guide]. Lisbon: Ministério do Trabalho e da Solidariedade.

INE. (2012, 2013). Estatísticas demográficas [Demographic Statistics]. Lisbon: INE.

Jarodzka, H., de Greef, M., Gouw, P., \& Brand-Gruwel, S. (2014). PIAAC results: Need for new approaches in improving adult literacy. Lifelong Learning in Europe. Available from: http:// www.elmmagazine.eu/articles/piaac-results-need-for-new-approaches-in-improving-adult-literacy

Marques, J. C., \& Góis, P. (2008). Imigrantes altamente qualificados em Portugal: uma tipologia [Highly skilled immigrants in Portugal: A typology]. In J. Peixoto (Org.), Revista Migrações Número Temático, Imigração e Mercado de Trabalho (pp. 73-94). Lisbon: ACIDI. Abril 2008, n. 2.

Martins, M. F. B. (2014). O Ensino não Formal na Aprendizagem de Português Língua Estrangeira em Contexto de Acolhimento - Um Estudo de Caso [Non-formal education in the learning of Portuguese as foreign language in the host society - A case study] (Unpublished master's thesis). FL-UL, Lisbon.

Morrison, T. G., Wilcox, B., Billen, M. T., Carr, S., Wilcox, G., Morrison, D., \& Wilcox, R. T. (2011). 50 years of "Literacy research and instruction": 1961-2011. Literacy Research and Instruction, 50 (4), 313-326.

de Oliveira, M. C. M. (2006). O ensino do português a adultos imigrantes: orientações e práticas [The teaching of Portuguese to adult immigrants: Practices and guidance] (Unpublished master's thesis). Universidade do Minho, Braga, Portugal.

Padilla, B., \& Ortiz, A. (2012). Fluxos migratórios em Portugal: do boom migratório à desaceleração no contexto de crise: Balanço e desafios [Migration flows in Portugal: From the migration boom to the slowdown in the context of crisis: Review and challenges]. REMHU, 39, 159-184.

Peixoto, J., \& Abreu, A. (2009). Demografia, mercado de trabalho e imigração de substituição: tendências, políticas e prospectiva no caso português [Demography, labour market and replacement migration: Trends, policies and prospective in the Portuguese case]. Análise Social, XLIV (193), 719-746.

Peixoto, J. Marçalo, C., \& Tolentino, N. C. (2011). Imigrantes e Segurança Social [Migrants and social security]. Lisbon: ACIDI.

Petrova, V. (Ed.). (2012). Foreign language learning for illiterate and functionally illiterate adults. ILLIAD Program paper, Intercultural Cooperation Foundation, Sofia (retrieved from http:// www.illiad.eu/images/PDF_files/illiad_program-paper-en.pdf).

Reste, C. D., \& Ançã, M. H. (2012). Diversidade Linguística e Cultural na Escola. "Fraqueza" ou "Riqueza"? [Linguistic and cultural diversity in school. "Weakness" or "enrichment"?]. Dossiê Temático, Currículo e Prática Pedagógica, Práxis Educacional, 8(13), 31-55. 
Santinho, C. (2012). A importância da competência cultural no atendimento de saúde a refugiados e requerentes de asilo [The importance of cultural competence in healthcare for refugees and asylum seekers]. Fórum Sociológico, Série II, 22, 73-81.

Schöneberger, C., van de Craats, I., \& Kurvers, J. (Eds.). (2011). Low educated adult second language and literacy acquisition. Proceedings of the 6th symposium, Cologne 2010. Nijmegen: Centre for Language Studies.

Schramm, K., \& Feick, D. (2011). Video-based teacher education material for German-as-a-secondlanguage literacy teachers. In C. Schöneberger, I. van de Craats, \& J. Kurvers (Eds.), Low educated adult second language and literacy acquisition. Proceedings of the 6th symposium, Cologne 2010 (pp. 89-102). Nijmegen: Centre for Language Studies.

SEF. (2013). Relatório de Imigração Fronteiras e Asilo [Alien and borders service report]. Lisbon: SEF/Departamento de Planeamento e Formação (Núcleo de Planeamento).

Semedo, M. G. (2011). Políticas de integração: o ensino/aprendizagem da língua portuguesa no contexto de acolhimento e integração de adultos imigrantes [Integration policies: Teaching and learning the Portuguese language in the context of receiving and integrating adult immigrants] (Unpublished master's thesis). FCSH, UNL, Lisbon.

Silva, A. (2003). Programa Portugal Acolhe. Estudo de Avaliação [Programme Portugal welcomes. impact study]. Lisbon: Departamento de Formação Profissional, Núcleo de Desenvolvimento Social e Profissional, IEFP e ISCTE.

Simpson, J. Sunderland, H., \& Cooke, M. (2007). Adult ESOL in the UK: Perspectives on Policy, Practice and Research. In M. Young-Scholten (Ed.), Low-educated second language and literacy acquisition. Proceedings of the Third Annual Forum (pp. 25-37). Durham: Roundtuit Publishing.

Sunderland, H. \& Moon, P. (2008). England: Policy development impacting on ESOL basic literacy. In I. van de Craats \& J. Kurvers (Eds.), Low-educated second language and literacy acquisition. Proceedings of the 4th symposium (pp. 185-194). Utrecht: LOT.

Távora, A., Vaz, H., \& Coimbra, J. (2012). A(s) Crise(s) da Educação e Formação de Adultos em Portugal [The crisis in adult education and training in Portugal]. Saber e Educar, 17, 28-40.

UNESCO. (2006). Chapter 6 - Understandings of literacy. Education for All Global Monitoring Report.

UNESCO. (2014) International Literacy Data 2014. http://www.uis.unesco.org/Literacy/Pages/ literacy-data-release-2014.aspx

Van de Craats, I., Kurvers, J., \& Young-Scholten, M. (2006). Research on low-educated second language and literacy acquisition. In I. van de Craats, J. Kurvers, \& M. Young-Scholten (Eds.), Low-educated adult second language and literacy acquisition: Proceedings of the inaugural symposium Tilburg 2005 (pp. 7-23). Utrecht: LOT.

Vinhas, M., \& Matias, R. (2002). Programa Portugal Acolhe. Estudo Sócio-Demográfico dos Formandos/Imigrantes 2001/2002 [Programme Portugal welcomes. Sociodemographic study of immigrant trainees 2001/2002]. Lisbon: Departamento de Formação Profissional, Núcleo de Desenvolvimento Social e Profissional, IEFP.

Young-Scholten, M., Peyton, J. K., Sosinski, M., \& Cabeza, A. M. (in press). Leslla teachers' views of the knowledge and skills they need: an international study. In I. van de Craats, J. Kurvers, \& R. van Hout (Eds.), Adult literacy, second language, and cognition. LESLLA Proceedings 2014. Nijmegen: Centre for Language Studies. 